\title{
PENGEMBANGAN INDEKS BIAYA KONSTRUKSI RUMAH SEJAHTERA MURAH DI BEBERAPA DAERAH DI INDONESIA
}

\section{The Development of the Construction Cost Indices of Low-Cost Housing in Several Regions in Indonesia}

\author{
Tabita Tania Libianto ${ }^{1}$, Andi $^{2}$, Lie Arijanto ${ }^{3}$ \\ ${ }^{1}$ Mahasiswa Program Studi Magister Teknik Sipil Universitas Kristen Petra \\ Alamat korespondesi : Jl. Siwalankerto No. 121-131 Telp. (031) 8439040 \\ Email : m01514007@john.petra.ac.id \\ ${ }^{2}$ Dosen Program Studi Magister Teknik Sipil Universitas Kristen Petra \\ Alamat korespondesi : Jl. Siwalankerto No. 121-131 Telp. (031) 8439040 \\ Email : andi@peter.petra.ac.id \\ ${ }^{3}$ Dosen Program Studi Magister Teknik Sipil Universitas Kristen Petra \\ Alamat korespondesi : Jl. Siwalankerto No. 121-131 Telp. (031) 8439040 \\ Email : arijanto_lie@yahoo.com
}

\begin{abstract}
Indonesian government develops Low-Cost Housing Program that spreads throughout Indonesia to fulfill the needs of those who are in need of houses. However, the housing costs vary among regions. If contractors have limited time and information, profit lost can be occured. The purpose of this research is to get information system, known as Construction Cost Indices (CCI), to ease the process of comparing costs among regions. CCI are made based on weight and price in each region. Price data found in 2015 Journal of Building Construction, Interior and Material Prices the 34th edition. CCI are developed by using Laspeyres Formula from material and labour cost weight in base region and Material Cost Indices $\left(I^{M}\right)$ and Labor Cost Indices $\left(I^{L}\right)$ from Eurostat. Base region is Jakarta. The results of this research are Material Cost Indices (MCI), Labor Cost Indices (LCI), and Construction Cost Indices (CCI), which are different among cities. MCI, LCI, and CCI are divided into six zones. MCI of Jakarta are in Zone 4, LCI of Jakarta are in Zone 6, and CCI of Jakarta. Tanggamus has the highest CCI in Indonesia.
\end{abstract}

Keywords : Regional Factors, Construction Cost Indices, Material Cost Indices, Labor Cost Indices, Low-Cost Housing

\begin{abstract}
Abstrak
Pemerintah Indonesia memiliki program pembangunan Rumah Sejahtera Murah yang tersebar di seluruh Indonesia untuk memenuhi kebutuhan masyarakat yang membutuhkan. Akan tetapi biaya di suatu daerah dengan biaya daerah lain tidaklah sama. Apabila kontraktor memiliki keterbatasan waktu dan informasi harga pada saat tender, mereka dapat mengalami kerugian dalam proyek luar daerah. Tujuan penelitian ini untuk mengusulkan sistem informasi yang dapat memudahkan dalam membandingkan biaya antar daerah yaitu berupa Indeks Biaya Konstruksi (CCI). Indeks Biaya Konstruksi (CCI) dibentuk dari bobot dan harga di tiap daerah. Data harga tersebut menggunakan data dari Jurnal Harga Satuan Bahan Bangunan Konstruksi dan Interior tahun 2015. Indeks menggunakan Laspeyres Formula dengan dibentuk dari bobot material dan upah (w) di kota dasar dan Indeks Biaya Material $\left(\mathrm{I}^{\mathrm{M}}\right)$ dan Indeks Biaya Upah $\left(\mathrm{I}^{\mathrm{L}}\right)$ dari Eurostat. Dasar indeks harga adalah kota Jakarta. Hasil penelitian adalah Indeks Biaya Material (MCI), Upah (LCI) dan Biaya Total (CCI), indeks - indeks tersebut tiap daerah memiliki perbedaan. Indeks dibagi dalam 6 zona. Indeks Biaya Material Jakarta berada di zona 4, Indeks Upah Jakarta berada di zona 6 dan indeks total Jakarta berada di zona 5. Indeks kota Tanggamus adalah yang paling tinggi.
\end{abstract}

Kata kunci : Faktor Regional, Indeks Biaya Konstruksi, Indeks Material, Indeks Upah, Rumah Sejahtera Murah 


\section{PENDAHULUAN}

Kebutuhan terhadap rumah tinggal meningkat karena berkembangnya pembangunan di Indonesia. Rumah Sejahtera Murah mulai dikembangkan pemerintah Indonesia untuk menyejahterakan rakyat yang berpenghasilan rendah untuk dapat memiliki rumah yang layak, sehat, aman, serasi, dan teratur, maka perlu pembangunan rumah yang dapat dilakukan secara bertahap.

Rumah Sejahtera Murah dikembangkan pemerintah Indonesia menyebar di seluruh Indonesia. Pemerintah Indonesia memiliki standar dan spesifikasi dari Rumah Sejahtera Murah ini yaitu dari Keputusan Menteri Pemukiman dan Prasarana Daerah (Kimpraswil) No. 403/KPTS/M/2002 dan Peraturan Menteri Negara Perumahan Rakyat No. 25 tahun 2011 (Menteri Pemukiman dan Prasarana Wilayah Republik Indonesia, 2002). Pendekatan penyediaan rumah selama ini lebih diseragamkan, sehingga terdapat beberapa kendala diantaranya kesenjangan harga yang sangat mencolok diantara beberapa daerah. Begitu pula menurut Deng et al (2010) bahwa bila ekonomi suatu daerah bertumbuh dengan cepat, maka permintaan barang material pada suatu daerah juga tinggi. Kebijakan harga yang tidak tepat dapat berdampak buruk bagi program tersebut. Harga Rumah Sejahtera Murah ini dapat sangat tinggi bila material dan upah didatangkan dari daerah lain. Di sisi lain ketika kegiatan konstruksi rendah, kompetisi menjadi intens, dan perusahaan konstruksi mulai menawar di pasar regional lain di mana mereka biasanya tidak beroperasi (Skitmore et al, 2006).

Padahal menurut Memon, et al (2010), biaya konstruksi ini merupakan salah satu kriteria utama terhadap kesuksesan proyek. Untuk menghindari biaya yang tinggi maka diperlukan informasi supplier di masingmasing kota proyek dan penggunaan tenaga lokal. Akan tetapi untuk mencari informasi harga material dan upah lokal diperlukan banyak waktu dan tenaga. Di sisi lain, kerap kali pengumpulan penawaran terkendali pada waktu.

Biaya konstruksi merupakan bagian yang krusial dalam proyek konstruksi. Terdapat beberapa faktor yang berpengaruh terhadap estimasi biaya proyek, yaitu dari faktor ukuran proyek, lokasi proyek, lingkungan proyek, iklim politik, iklim ekonomi, variasi dari faktor regional dan lain sebagainya (Oginni et al, 2014). Faktor perbedaan kota atau disebut juga faktor regional ini merupakan salah satu ketidakpastian yang menyebabkan biaya membengkak. Oleh karena ketidakpastian dari faktor regional ini maka diperlukan data dan informasi proyek yang akurat. Data dan informasi proyek yang kurang lengkap adalah penyebab overruns biaya (Santoso, 1999). Maka faktor regional yaitu lokasi proyek harus diperhatikan oleh pihak kontraktor.

Akan tetapi dalam mengatasi faktor regional ini bukan perkara yang mudah. Hal tersebut dikarenakan sedikitnya informasi dan keterbatasan waktu tender. Maka dari itu mulai dikembangkan indeks biaya konstruksi. Indeks Biaya Konstruksi ini memberikan dasar dalam menentukan harga penawaran (Gockov et al, 2012). Indeks Biaya Konstruksi sangat bermanfaat bagi kepentingan penyesuaian atau perkiraan biaya aktivitas konstruksi (Hwang, 2009).

Wibowo et al (2013) pernah membahas mengenai Indeks Biaya Konstruksi dengan menggunakan Pratt Method (1987). Namun indeks hasil penelitian Wibowo ini hanya terbatas untuk nilai total bangunan dan belum meninjau harga untuk masing - masing material dan upah kerja. Tujuan dalam penelitian ini adalah untuk mengusulkan Indeks Biaya Konstruksi, Indeks Harga Material dan Indeks Upah Rumah Sejahtera Murah di beberapa daerah di Indonesia pada tahun 2015, dan melihat zonasi Indeks Biaya Konstruksi, Indeks harga material dan indeks upah Rumah Sejahtera Murah di beberapa daerah di Indonesia tahun 2015.

\section{Index Biaya}

Terdapat 3 indeks biaya menurut Statistics Directorate (n.d.) : input price index, output prices index, dan seller's price index. Gambar 1 menunjukan 3 indeks biaya. 
Input Price Index Output Price Index Seller's Price Index

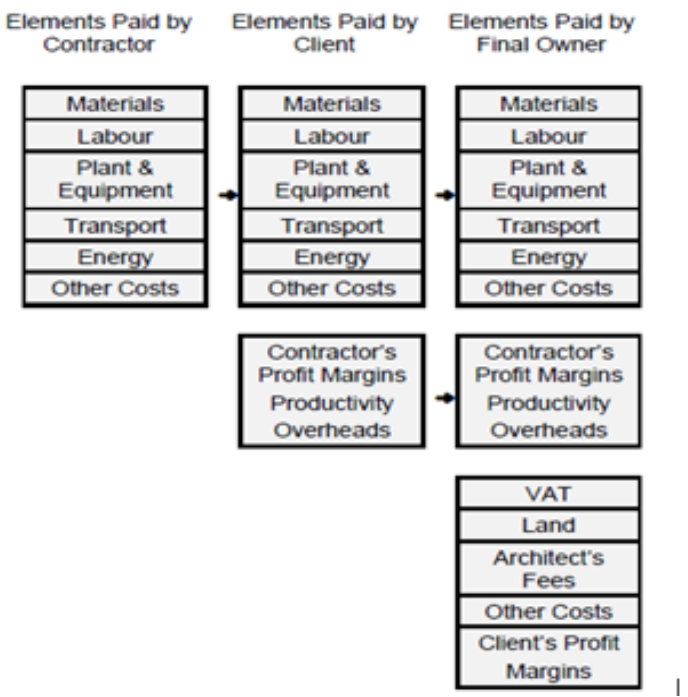

Gambar 1. Macam - Macam Indeks Biaya

Sumber : Statistics Directorate (n.d.)

Biaya yang terlibat pada input price index adalah biaya yang terjadi pada proses pembangunan. Biaya pada output price index adalah biaya yang dikeluarkan developer kepada kontraktor. Biaya yang terlibat pada seller's price index ini adalah biaya yang ada antara penjual dengan pembeli bangunan tersebut (end user).

Pada penelitian ini digunakan Indeks Biaya Konstruksi yang merupakan input price index. Dengan mengetahui indeks biaya konstruksi maka akan mudah dilihat perbandingan biaya konstruksi, material dan upah di berbagai kota. Kegunaan indeks biaya adalah untuk membandingkan biaya antara satu kota dengan kota lain dan mengukur perubahan dimana harus ada variabel dasar sebagai acuan (Ashworth, 1988).

Terdapat beberapa penelitian yang membahas mengenai indeks biaya konstruksi antara lain pengembangan indeks biaya konstruksi di Eropa oleh Eurostat (2006) dan Wibowo et al (2013).

\section{Eurostat (2006)}

Eurostat mempelajari mengenai indeks biaya konstruksi pada beberapa negara di Eropa. Pada indeks ini dibatasi 2 elemen pembentuk yaitu biaya material dan upah. Indeks biaya konstruksi dilihat dari dari total biaya bangunan. Indeks Biaya Konstruksi terbentuk dari bobot di kota dasar dan indeks material dan upah. Indeks material dan upah antar daerah didapatkan dengan menggunakan Laspeyres formula yaitu perbandingan biaya antar daerah yang satu dengan yang lain yang pada penelitian ini dan akan dijelaskan di subbab Hasil dan Pembahasan.

Dari masing - masing indeks material dan upah yang terbentuk tersebut dapat dibentuk indeks biaya konstruksi. Indeks yang dihasilkan berlaku dengan asumsi:

- Teknik pelaksanaan dan organisasi tidak berubah

- Produktivitas pekerja dianggap sama antar daerah

- Tidak ada perubahan material/alat

Banyak negara di Eropa yang menggunakan Laspeyres Formula dalam membentuk Indeks Biaya (Yu dan Ive, 2008). Perhitungan Indeks Biaya Konstruksi dengan menggunakan nilai total bangunan lebih merepresentatifkan indeks suatu bangunan karena mencakup semua material dan upah yang terlibat. Dalam pembentukan Indeks Biaya Konstruksi dengan metode dari Eurostat ini juga melibatkan Indeks Biaya Material dan Indeks Biaya Upah. Sehingga dengan menggunakan metode secara otomatis juga dapat membentuk indeks biaya masing - masing material dan upah, dimana indeks ini akan membantu dalam melihat perbandingan harga masing - masing material dan upah antar daerah.

\section{Wibowo et al (2013)}

Wibowo et al (2013) mengusulkan Indeks Biaya Konstruksi tahun 2011 dengan menggunakan studi kasus Rumah Sejahtera Murah satu lantai $36 \mathrm{~m}^{2}$ sesuai dengan Keputusan Menteri Pemukiman dan Prasarana Daerah (Kimpraswil) No. 403/KPTS/M/2002 dan Peraturan Menteri Negara Perumahan Rakyat No. 25 tahun 2011 (Menteri Pemukiman dan Prasarana Wilayah Republik Indonesia, 2002). Penelitian tersebut menggunakan data sekunder untuk harga material dan upah dari Jurnal Harga Satuan Bangunan Konstruksi dan Interior Edisi XXXI, sedangkan untuk analisa harga digunakan Standar Nasional Indonesia (SNI) tentang tata cara perhitungan harga satuan untuk bangunan gedung dan perumahan tahun 2008. Item pembentuk indeks hanya diambil dari item yang sensitif di kota Jakarta, dimana dalam mencari indeks kota lain juga menggunakan batasan item 
pembentuk indeks yang sama dengan Jakarta. Indeks ini didapatkan dari hasil simulasi menggunakan metode Pratt (1987).

Metode penelitian pembentuk Indeks Biaya Konstruksi memiliki banyak alternatif pilihan. Wibowo et al (2013) membatasi item biaya sensitif di kota Jakarta yang menjadi komponen pembentuk Indeks Biaya Konstruksi. Penentuan Indeks Biaya Konstruksi menggunakan nilai total bangunan lebih mencerminkan indeks harga bangunan secara utuh. Selain itu item biaya sensitif belum tentu sama antar daerah yang satu dengan yang lain.

\section{Rumah Sejahtera Murah}

Untuk meningkatkan kesejahteraan rakyat maka Rumah Sejahtera Murah akan ditujukan untuk menjadi rumah masal bagi masyarakat. Rumah Sejahtera Murah yang digunakan adalah rumah satu lantai dengan luas $36 \mathrm{~m}^{2}$. Desain Rumah Sejahtera Murah ini diambil dari Keputusan Menteri Pemukiman dan Prasarana Daerah (Kimpraswil) No. 403/KPTS/M/2002 dan Peraturan Menteri Negara Perumahan Rakyat No. 25 tahun 2011. (Menteri Pemukiman dan Prasarana Wilayah Republik Indonesia, 2002). Rumah ini memiliki spesifikasi pondasi batu kali, dinding conblok tanpa plester, cor rabat lantai, kusen kayu, plafon eternit dan atap asbes. Gambar 2. menunjukan desain dari Rumah Sejahtera Murah.

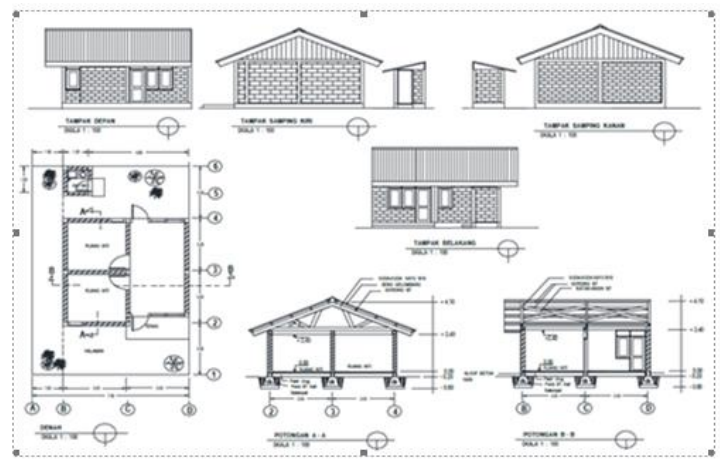

Gambar 2. Desain Rumah Sejahtera Murah

Dari Eurostat (2006) dan penelitian Wibowo et al (2013) tersebut selanjutnya pada paper ini akan dibahas pembentukan Indeks Biaya Konstruksi dengan metode Eurostat dan menggunakan studi kasus Rumah Sejahtera Murah oleh Menteri Pemukiman dan Prasarana Wilayah Republik Indonesia (2002)

\section{METODE PENELITIAN \\ Pemilihan Desain dan Perhitungan: Rumah Sejahtera Murah}

Penelitian dimulai dengan mempelajari desain Rumah Sejahtera Murah berdasarkan Keputusan Menteri Pemukiman dan Prasarana Daerah (Kimpraswil) No. 403/KPTS/M/2002 dan Peraturan Menteri Negara Perumahan Rakyat No. 25 tahun 2011, dan dilanjutkan dengan menentukan kebutuhan material dan upah pekerja. Ada 35 jenis material dan 6 jenis upah harian yang dipakai pada desain Rumah Sejahtera Murah ini.

Material yang digunakan meliputi : kaso meranti 5/7, papan meranti 2/20, kayu balok 6/12, kayu 5/10, paku $7 \mathrm{~cm}$, paku $10 \mathrm{~cm}$, paku seng, batu kali, semen, pasir pasang, pasir beton, pasir urug, split, conblock, besi beton $\varnothing 12$, besi beton $\varnothing 8$, kawat bendrat, kaca $3 \mathrm{~mm}$, tripleks $6 \mathrm{~mm}$, tripleks $3 \mathrm{~mm}$, seng plat, asbes gelombang, wuwung asbes, eternit asbes, bak mandi, kloset jongkok, floor drain, pipa PVC Ø1/2", kran, pipa PVC Ø4”, pipa PVC Ø3”, lampu, stop kontak, saklar, kabel, MCB. Sedangkan upah yang ditinjau meliputi upah harian dari : pekerja, tukang batu, tukang kayu, tukang besi, kepala tukang dan mandor.

Langkah berikutnys dilakukan pengumpulan data berupa harga material dan upah pada masing - masing daerah dengan menggunakan data sekunder dari Jurnal Harga Satuan Bangunan Konstruksi dan Interior tahun 2015 Edisi 34 (Pandu Bangun Persada Nusantara, 2015). Kemudian dilakukan penentuan kebutuhan bahan dan upah dengan mengolah data menggunakan Standar Nasional Indonesia (SNI) tentang tata cara perhitungan harga satuan untuk bangunan gedung dan perumahan tahun 2011 (Badan Standar Nasional Indonesia, 2011). Setelah mendapatkan data tersebut lalu dihitung nilai total bangunan.

\section{Pembobotan}

Nilai total bangunan yang dihasilkan selanjutnya digunakan untuk menghitung bobot biaya pada kota dasar yaitu Jakarta. Kota Jakarta diambil sebagai kota dasar karena merupakan ibukota dan banyak pelaku konstruksi di kota tersebut. Rumus untuk perhitungan pembobotan material di kota dasar (Jakarta) adalah sebagai berikut:

$$
\mathrm{w}^{\mathrm{MT}}=\left(\mathrm{V} \times \mathrm{U}_{\mathrm{J}}^{\mathrm{M}}\right) / \mathrm{T}_{\mathrm{J}} \times 100 \%
$$


$\mathrm{w}^{\mathrm{MT}}=$ bobot biaya material terhadap

$\mathrm{V}=$ Volume biaya total bangunan

$\mathrm{U}_{\mathrm{J}}=$ harga material per unit

$\mathrm{T}_{\mathrm{J}}=$ total biaya bangunan

Dengan cara yang sama, dapat dihitung bobot biaya masing - masing upah terhadap biaya total di kota dasar (Jakarta):

$\mathrm{w}^{\mathrm{LT}}=\left(\mathrm{V} \times \mathrm{U}_{\mathrm{J}}^{\mathrm{L}}\right) / \mathrm{T}_{\mathrm{J}} \times 100 \%$

$\mathrm{w}^{\mathrm{LT}}=$ bobot biaya upah terhadap biaya total bangunan

$\mathrm{V}=$ Volume

$\mathrm{U}_{\mathrm{J}}=$ upah per unit

$\mathrm{T}_{\mathrm{J}} \quad=$ total biaya bangunan

Untuk membentuk Material Cost Index (MCI) dan Labor Cost Index (LCI), maka diperlukan perhitungan bobot biaya masing masing material terhadap biaya total material di kota dasar dan bobot biaya masing masing upah terhadap biaya total di kota dasar berikut adalah rumusannya :

$\mathrm{w}^{\mathrm{MM}}=\left({\mathrm{V} \times \mathrm{U}^{\mathrm{M}}}_{\mathrm{J}}\right) / \mathrm{T}_{\mathrm{J}}^{\mathrm{M}_{\mathrm{J}}} 100 \%$

$\mathrm{w}^{\mathrm{MM}}=$ bobot biaya material terhadap biaya total material

$\mathrm{V}=$ Volume

$\mathrm{U}_{\mathrm{J}}=$ harga material per unit

$\mathrm{T}^{\mathrm{M}}{ }_{\mathrm{J}}=$ total biaya material

$$
\begin{aligned}
& \mathrm{w}^{\mathrm{LL}}=\left(\mathrm{V}^{\mathrm{L}} \mathrm{U}_{\mathrm{J}}\right) / \mathrm{T}_{\mathrm{J}} \times 100 \% \\
& \mathrm{w}^{\mathrm{LL}}=\text { bobot biaya upah terhadap biaya } \\
& \quad \text { total upah } \\
& \mathrm{V}=\text { Volume } \\
& \mathrm{U}^{\mathrm{L}}=\text { upah per unit } \\
& \mathrm{T}_{\mathrm{J}}=\text { total biaya upah }
\end{aligned}
$$

\section{Indeks Biaya}

Harga material dan upah juga digunakan untuk membentuk indeks biaya material dan upah menggunakan Laspeyres Formula (Eurostat, 2006). Berikut adalah perhitungan Indeks Biaya Material di kota A:

$$
\begin{aligned}
& \mathrm{I}_{\mathrm{A}}^{\mathrm{M}}= \mathrm{U}_{\mathrm{A}}^{\mathrm{M}} / \mathrm{U}^{\mathrm{M}} \mathrm{X} 100 \\
& \mathrm{I}^{\mathrm{M}} \mathrm{A}=\text { Indeks Biaya Material per unit } \\
& \mathrm{U}^{\mathrm{M}} \mathrm{A}=\text { harga material per unit } \\
& \mathrm{U}_{\mathrm{J}}^{\mathrm{M}}= \text { harga material per unit di kota } \\
& \text { dasar }
\end{aligned}
$$

Dengan rumusan yang sama dapat membentuk Indeks Biaya Upah di kota A seperti berikut:

$$
\begin{aligned}
& \mathrm{I}_{\mathrm{A}}^{\mathrm{L}}=\mathrm{U}_{\mathrm{A}}^{\mathrm{L}} / \mathrm{U}_{\mathrm{J}}^{\mathrm{L}} \mathrm{x} 100 \\
& \mathrm{I}_{\mathrm{A}}^{\mathrm{L}}=\mathrm{Indeks} \text { Biaya upah per unit } \\
& \mathrm{U}_{\mathrm{A}}^{\mathrm{L}}=\text { upah per unit } \\
& \mathrm{U}_{\mathrm{J}}^{\mathrm{L}}=\text { upah per unit di kota dasar }
\end{aligned}
$$

Bobot item material dan upah pada kota dasar, indeks biaya material dan indeks biaya upah di kota A digunakan untuk membangun Indeks Biaya Konstruksi yaitu indeks nilai total bangunan di kota $\mathrm{A}$.

$$
\begin{aligned}
& \mathrm{CCI}=\Sigma\left(\mathrm{w}^{\mathrm{MT}} \mathrm{XI}^{\mathrm{M}}\right)+\Sigma\left(\mathrm{w}^{\mathrm{LT}} \mathrm{xI}{ }^{\mathrm{L}}\right) \\
& \mathrm{CCI}=\text { Construction Cost Index (Indeks } \\
& \text { Biaya Konstruksi) } \\
& \mathrm{I}^{\mathrm{M}}=\text { Indeks Biaya Material } \\
& \mathrm{I}^{\mathrm{L}} \quad=\text { Indeks Biaya Upah } \\
& \mathrm{w}^{\mathrm{MT}}=\text { bobot biaya masing - masing } \\
& \text { material terhadap biaya total di } \\
& \text { kota dasar (Jakarta) } \\
& \mathrm{w}^{\mathrm{LT}}=\text { bobot biaya masing - masing }
\end{aligned}
$$

Jumlah kota sample pada penelitian ini adalah 71 kota. Dari indeks tersebut dilakukan pemetaan indeks untuk membentuk zonasi CCI di Indonesia. Selain menghitung indeks biaya konstruksi (CCI), pada penelitian ini juga akan dilihat indeks biaya total material (MCI) dan indeks biaya total upah (LCI) di masing masing daerah. Berikut adalah rumusan indeks biaya total material dan indeks biaya total upah di kota A:

$$
\begin{aligned}
& \mathrm{MCI}=\Sigma\left(\mathrm{w}^{\mathrm{MM}} \times \mathrm{I}^{\mathrm{M}}\right) \\
& \mathrm{LCI}=\Sigma\left(\mathrm{w}^{\mathrm{LL}} \times \mathrm{I}^{\mathrm{L}}\right) \\
& \text { MCI }=\text { Material Cost Index (Indeks } \\
& \text { Biaya Total Material) } \\
& \text { LCI }=\text { Labor Cost Index (Indeks Biaya } \\
& \text { Total Upah) } \\
& \mathrm{w}^{\mathrm{MM}}=\text { bobot biaya material terhadap } \\
& \text { biaya total material di kota dasar } \\
& \text { (Jakarta) } \\
& \mathrm{w}^{\mathrm{LL}}=\text { bobot biaya upah terhadap biaya } \\
& \text { total upah di kota dasar (Jakarta) }
\end{aligned}
$$

\section{HASIL DAN PEMBAHASAN \\ Bobot Biaya di Kota Dasar (Jakarta)}

Biaya total konstruksi $\left(\mathrm{T}_{\mathrm{J}}\right)$ untuk Rumah Sejahtera Murah di kota dasar (Jakarta) adalah Rp 68.290.582, meliputi biaya total material $\left(\mathrm{T}_{\mathrm{J}}^{\mathrm{M}}\right)$ sebesar $\mathrm{Rp}$ 40.698.640 dan biaya total upah $\left(\mathrm{T}_{\mathrm{J}}\right)$ sebesar Rp 21.383.707. Perhitungan volume pekerjaan, analisa kebutuhan bahan, dan analisa harga satuan selengkapnya dapat dilihat pada Libianto (2016).

Dari nilai total bangunan ini, didapatkan bobot masing - masing biaya material dan upah. Contoh perhitungan untuk material kaso adalah sebagai berikut : 


$$
\begin{aligned}
\mathrm{w}^{\mathrm{MT}}= & \left(\mathrm{V} \times \mathrm{U}^{\mathrm{M}_{\mathrm{J}}}\right) / \mathrm{T}_{\mathrm{J}} \times 100 \% \\
\mathrm{w}^{\mathrm{MT}}= & (37,65 \text { batang } \times \mathrm{Rp} 74.880) / \mathrm{Rp} \\
& 68.290 .582 \times 100 \\
= & 4,13 \%
\end{aligned}
$$

Bobot $\left(\mathrm{w}^{\mathrm{MT}}\right.$ dan $\mathrm{w}^{\mathrm{LT}}$ ) berguna untuk membentuk Indeks Biaya Konstruksi (CCI). Untuk memudahkan melihat perbandingan harga material dan upah antar daerah maka perlu dihitung pula indeks biaya total material (MCI) dan indeks biaya total upah (LCI). Untuk menghitung indeks biaya total material (MCI) dan indeks biaya total upah (LCI) maka dilakukan perhitungan bobot berdasarkan nilai total material $\left(\mathrm{w}^{\mathrm{MM}}\right)$ atau nilai total upah $\left(w^{\mathrm{LL}}\right)$. Berikut contoh perhitungan bobot kaso terhadap biaya total material $\left(\mathrm{w}^{\left.\mathrm{MM}_{\text {kaso }}\right)}\right.$ yang digunakan untuk menghitung Indeks Biaya Total Material (MCI) dengan menggunakan Rumus (3):

$$
\begin{aligned}
& \mathrm{w}^{\mathrm{MM}_{\text {kaso }}}=\left(\mathrm{V} \times \mathrm{U}_{\mathrm{J}}^{\mathrm{M}}\right) / \mathrm{T}_{\mathrm{J}}^{\mathrm{M}_{\mathrm{J}}} 100 \%
\end{aligned}
$$

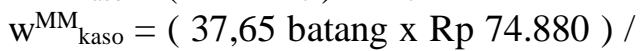

$$
\begin{aligned}
& \text { Rp } 40.698 .640 \times 100 \% \\
& =6,92 \%
\end{aligned}
$$

\begin{tabular}{|c|c|c|c|c|c|c|c|}
\hline No & $\begin{array}{c}\text { ITEM BIAYA } \\
\text { MATERIAL \& } \\
\text { UPAH }\end{array}$ & $\begin{array}{l}\text { VOLU } \\
\text { ME (V) }\end{array}$ & $\begin{array}{l}\text { SAT } \\
\text { UAN }\end{array}$ & $\begin{array}{l}\text { Hrg Sat. Jakarta } \\
\left(\mathrm{U}_{\mathrm{J}}^{\mathrm{M}} \text { dan } \mathrm{U}_{\mathrm{J}}\right) \\
(\mathrm{Rp})\end{array}$ & $\begin{array}{l}\text { Juml. } \\
\text { Jakarta } \\
\text { (Rp) }\end{array}$ & $\begin{array}{l}\mathrm{w}^{\mathrm{MM}} \text { dan } \\
\mathrm{w}^{\mathrm{LL}}(\%)\end{array}$ & $\begin{array}{c}\mathrm{w}^{\mathrm{MT}} \mathrm{dan}^{\mathrm{LT}} \mathrm{w}^{\mathrm{LT}}(\%)\end{array}$ \\
\hline & Material & & & & & & \\
\hline 1 & $\begin{array}{l}\text { Kaso 5/7 - } 4 \text { m } \\
\text { meranti }\end{array}$ & 37.65 & btg & 74,830 & $2,817,350$ & 6.92 & 4.13 \\
\hline 2 & $\begin{array}{l}\text { Papan } 2 / 20-4 m \\
\text { meranti }\end{array}$ & 50.3 & $\operatorname{lmbr}$ & 72,080 & $3,625,624$ & 8.91 & 5.31 \\
\hline 3 & Kayu balok $6 / 12$ & 0.45256 & m3 & $4,457,500$ & $2,017,300$ & 4.96 & 2.95 \\
\hline 4 & Kayu 5/10 & 101.275 & btg & 89,150 & $9,028,666$ & 22.18 & 13.22 \\
\hline 5 & Paku $7 \mathrm{~cm}$ & 12.9994 & $\mathrm{~kg}$ & 16,500 & 214,490 & 0.53 & 0.31 \\
\hline 6 & Paku $10 \mathrm{~cm}$ & 5.935 & $\mathrm{~kg}$ & 15,560 & 92,349 & 0.23 & 0.14 \\
\hline 7 & Paku seng/asbes & 7.652 & $\mathrm{~kg}$ & 25,480 & 194,973 & 0.48 & 0.29 \\
\hline 8 & Batu kali & 2.34 & $\mathrm{~m} 3$ & 290,823 & 680,526 & 1.67 & 1.00 \\
\hline 9 & Semen & 37.8876 & zak & 65,185 & $2,469,703$ & 6.07 & 3.62 \\
\hline 10 & Pasir pasang & 14.1648 & m3 & 282,536 & $4,002,066$ & 9.83 & 5.86 \\
\hline 11 & Pasir beton & 3.5946 & $\mathrm{~m} 3$ & 277,385 & 997,088 & 2.45 & 1.46 \\
\hline 12 & Pasir urug & 1.8 & m3 & 279,224 & 502,603 & 1.23 & 0.74 \\
\hline 13 & Split & 3.1149 & m3 & 280,680 & 874,290 & 2.15 & 1.28 \\
\hline 14 & Conblok & 506.25 & bh & 2,536 & $1,283,850$ & 3.15 & 1.88 \\
\hline 15 & Besi $\emptyset 12$ & 29.8542 & btg & 128,114 & $3,824,755$ & 9.40 & 5.60 \\
\hline 16 & Besi Ø8 & 28.4681 & btg & 56,940 & $1,620,968$ & 3.98 & 2.37 \\
\hline 17 & Kawat baja & 6.345 & $\mathrm{~kg}$ & 19,917 & 126,373 & 0.31 & 0.19 \\
\hline 18 & Kaca $3 \mathrm{~mm}$ & 8 & $\mathrm{~m} 2$ & 73,000 & 584,000 & 1.43 & 0.86 \\
\hline 19 & Tripleks $6 \mathrm{~mm}$ & 4.807 & $\operatorname{lmbr}$ & 95,000 & 456,665 & 1.12 & 0.67 \\
\hline 20 & Tripleks $3 \mathrm{~mm}$ & 0.576 & $\operatorname{lmbr}$ & 52,910 & 30,476 & 0.07 & 0.04 \\
\hline 21 & Seng plat bjls 36 & 2.01 & $\mathrm{~m} 2$ & 65,000 & 130,650 & 0.32 & 0.19 \\
\hline 22 & Asbes gelombang & 32.64 & $\operatorname{lmbr}$ & 36,580 & $1,193,971$ & 2.93 & 1.75 \\
\hline 23 & Wuwung asbes & 6.7 & $\operatorname{lmbr}$ & 26,775 & 179,393 & 0.44 & 0.26 \\
\hline 24 & Eternit asbes & 35.2 & $1 \mathrm{mbr}$ & 32,500 & $1,144,000$ & 2.81 & 1.68 \\
\hline 25 & Bak mandi & 1 & bh & 220,000 & 220,000 & 0.54 & 0.32 \\
\hline 26 & Kloset jongkok & 1 & bh & 232,000 & 232,000 & 0.57 & 0.34 \\
\hline 27 & Floor drain & 1 & bh & 10,000 & 10,000 & 0.02 & 0.01 \\
\hline 28 & Pipa pvc 1/2" & 1 & btg & 15,730 & 15,730 & 0.04 & 0.02 \\
\hline
\end{tabular}

Tabel 1. menunjukan nilai bobot masing - masing material $\left(\mathrm{w}^{\mathrm{MM}}\right.$ dan $\left.\mathrm{w}^{\mathrm{MT}}\right)$ dan upah $\left(w^{\mathrm{LL}}\right.$ dan $\left.\mathrm{w}^{\mathrm{LT}}\right)$.

Tabel 1. Bobot Biaya di Kota Jakarta 
Lanjutan Tabel 1. Bobot Biaya di Kota Jakarta

\begin{tabular}{|c|c|c|c|c|c|c|c|}
\hline No & $\begin{array}{c}\text { ITEM BIAYA } \\
\text { MATERIAL \& } \\
\text { UPAH }\end{array}$ & $\begin{array}{l}\text { VOLU } \\
\text { ME (V) }\end{array}$ & $\begin{array}{l}\text { SAT } \\
\text { UAN }\end{array}$ & $\begin{array}{l}\text { Hrg Sat. Jakarta } \\
\left(\mathrm{U}_{\mathrm{J}}^{\mathrm{M}} \text { dan } \mathrm{U}_{\mathrm{J}}^{\mathrm{L}}\right) \\
(\mathrm{Rp})\end{array}$ & $\begin{array}{l}\text { Juml. } \\
\text { Jakarta } \\
\text { (Rp) }\end{array}$ & $\begin{array}{l}\mathrm{w}^{\mathrm{MM}} \text { dan } \\
\mathrm{w}^{\mathrm{LL}}(\%)\end{array}$ & $\begin{array}{c}\mathrm{w}^{\mathrm{MT}} \text { dan } \mathrm{w}^{\mathrm{LT}} \\
(\%)\end{array}$ \\
\hline 29 & Keran & 2 & bh & 150,000 & 300,000 & 0.74 & 0.44 \\
\hline 30 & Pipa PVC 4" & 4 & btg & 212,960 & 851,840 & 2.09 & 1.25 \\
\hline 31 & Pipa PVC 3" & 3 & btg & 128,480 & 385,440 & 0.95 & 0.56 \\
\hline 32 & Titik lampu & 5 & bh & 32,000 & 160,000 & 0.39 & 0.23 \\
\hline 33 & Stop kontak & 4 & bh & 25,400 & 101,600 & 0.25 & 0.15 \\
\hline 34 & Saklar & 3 & bh & 18,300 & 54,900 & 0.13 & 0.08 \\
\hline 35 & Kabel & 25 & $\mathrm{~m}$ & 5,000 & 125,000 & 0.31 & 0.18 \\
\hline \multirow[t]{13}{*}{36} & Panel Kontrol & 1 & unit & 150,000 & 150,000 & 0.37 & 0.22 \\
\hline & TOTAL MATERIAL & & & & $40,698,640$ & 100.00 & 59.60 \\
\hline & Upah & & & & & & \\
\hline & - pekerja & 72.2251 & $\mathrm{OH}$ & 102,920 & $7,433,409$ & 34.76 & 10.88 \\
\hline & - tukang batu & 17.8673 & $\mathrm{OH}$ & 121,230 & $2,166,047$ & 10.13 & 3.17 \\
\hline & - tukang kayu & 75.5484 & $\mathrm{OH}$ & 121,230 & $9,158,738$ & 42.83 & 13.41 \\
\hline & - tukang besi & 2.961 & $\mathrm{OH}$ & 121,230 & 358,962 & 1.68 & 0.53 \\
\hline & - kepala tukang & 11.1477 & $\mathrm{OH}$ & 139,574 & $1,555,924$ & 7.28 & 2.28 \\
\hline & - mandor & 4.50046 & $\mathrm{OH}$ & 157,901 & 710,627 & 3.32 & 1.04 \\
\hline & TOTAL UPAH & & & & $21,383,707$ & 100 & 31 \\
\hline & $\begin{array}{l}\text { Contingency + } \\
\text { overhead }(10 \%)\end{array}$ & & & & $6,208,235$ & 100.00 & 9.09 \\
\hline & TOTAL & & & & $6,208,235$ & 100.00 & 9.09 \\
\hline & TOTAL & & & & $68,290,582$ & & 100 \\
\hline
\end{tabular}

\section{Index Biaya Material dan Upah}

Indeks biaya material dan upah (MCI dan LCI) diperoleh dari harga material dan upah $\left(\mathrm{U}_{\mathrm{J}}\right.$ dan $\left.\mathrm{U}_{\mathrm{J}}\right)$ masing - masing kota yang sudah dibandingkan dengan harga di kota dasar. Indeks biaya ini menggunakan Laspeyres Formula. Indeks kota dasar yaitu Jakarta bernilai 100 . Berikut adalah contoh perhitungan indeks kaso 5/7 meranti di kota Medan dengan Formula (5) :

$$
\begin{aligned}
\mathrm{I}^{\text {Kaso }}{ }_{\text {Medan }} & =\mathrm{U}^{\text {Kaso }}{ }_{\text {Medan }} / \mathrm{U}^{\text {Kaso }}{ }_{\text {JakartaX }} \mathrm{I}^{\text {Kaso }}{ }_{\text {Jakarta }} \\
& =\mathrm{Rp} 46.802 / \mathrm{Rp} 74.391 \times 100 \\
& =62,91
\end{aligned}
$$

Tabel 2 menampilkan indeks material

\begin{tabular}{|c|c|c|c|c|c|c|c|c|c|c|c|}
\hline No & $\begin{array}{c}\text { Item Biaya } \\
\text { Material \& } \\
\text { Upah }\end{array}$ & $\begin{array}{c}\text { DKI } \\
\text { Jakarta }\end{array}$ & $\begin{array}{l}\text { Medan - } \\
\text { SUMUT }\end{array}$ & $\begin{array}{l}\text { SUM- } \\
\text { BAR }\end{array}$ & $\begin{array}{c}\text { Pekan- } \\
\text { baru }\end{array}$ & Kampar & Dumai & Inhu & $\begin{array}{l}\text { Btg } \\
\text { Hari }\end{array}$ & Bungo & Jambi \\
\hline 1 & Kaso 5/7 & 1.00 & 0.71 & 0.38 & 0.44 & 0.34 & 0.37 & 0.35 & 0.44 & 0.44 & 0.51 \\
\hline 2 & Papan 2/20 & 1.00 & 0.84 & 0.56 & 0.52 & 0.41 & 0.43 & 0.42 & 0.54 & 0.53 & 0.54 \\
\hline 3 & Kayu balok $6 / 12$ & 1.00 & 0.85 & 0.78 & 0.53 & 0.41 & 0.44 & 0.42 & 0.53 & 0.53 & 0.61 \\
\hline 4 & Кауu 5/10 & 1.00 & 0.85 & 0.46 & 0.53 & 0.41 & 0.44 & 0.42 & 0.53 & 0.53 & 0.61 \\
\hline 5 & Paku $7 \mathrm{~cm}$ & 1.00 & 1.33 & 0.99 & 1.13 & 1.26 & 0.85 & 0.95 & 1.17 & 1.09 & 0.85 \\
\hline 6 & Paku $10 \mathrm{~cm}$ & 1.00 & 1.41 & 1.05 & 1.20 & 1.34 & 0.90 & 1.00 & 1.24 & 1.16 & 0.90 \\
\hline 7 & Paku seng/asbes & 1.00 & 1.66 & 0.94 & 0.94 & 1.02 & 1.59 & 1.24 & 0.78 & 1.08 & 0.78 \\
\hline 8 & Batu kali & 1.00 & 0.53 & 0.57 & 1.09 & 1.00 & 1.24 & 1.26 & 1.23 & 1.12 & 1.27 \\
\hline 9 & Semen & 1.00 & 1.11 & 1.10 & 0.94 & 0.96 & 0.91 & 1.00 & 0.98 & 0.97 & 1.00 \\
\hline 10 & Pasir pasang & 1.00 & 0.47 & 0.53 & 0.38 & 0.37 & 0.47 & 0.25 & 0.40 & 0.43 & 0.31 \\
\hline 11 & Pasir beton & 1.00 & 0.48 & 0.54 & 0.46 & 0.44 & 1.16 & 0.25 & 0.43 & 0.49 & 0.32 \\
\hline 12 & Pasir urug & 1.00 & 0.41 & 0.32 & 0.37 & 0.35 & 0.54 & 0.26 & 0.34 & 0.43 & 0.32 \\
\hline 13 & Split & 1.00 & 0.86 & 0.76 & 1.46 & 1.41 & 1.47 & 1.33 & 1.26 & 1.06 & 1.09 \\
\hline 14 & $\begin{array}{l}\text { Conblock } \\
40 \times 20 \times 10\end{array}$ & 1.00 & 1.58 & 1.18 & 1.23 & 1.15 & 1.56 & 1.03 & 1.62 & 1.73 & 1.74 \\
\hline
\end{tabular}
dan upah di beberapa daerah.

Tabel 2. Indeks Material dan Upah di Beberapa Daerah 
Lanjutan Tabel 2. Indeks Material dan Upah di Beberapa Daerah

\begin{tabular}{|c|c|c|c|c|c|c|c|c|c|c|c|}
\hline No & $\begin{array}{c}\text { Item Biaya } \\
\text { Material \& } \\
\text { Upah }\end{array}$ & $\begin{array}{c}\text { DKI } \\
\text { Jakarta }\end{array}$ & $\begin{array}{l}\text { Medan - } \\
\text { SUMUT }\end{array}$ & $\begin{array}{l}\text { SUM- } \\
\text { BAR }\end{array}$ & $\begin{array}{l}\text { Pekan- } \\
\text { baru }\end{array}$ & Kampar & Dumai & Inhu & $\begin{array}{l}\text { Btg } \\
\text { Hari }\end{array}$ & Bungo & Jambi \\
\hline 15 & Besi $\varnothing 12$ & 1.00 & 1.37 & 0.90 & 0.75 & 0.77 & 0.76 & 0.75 & 1.23 & 1.25 & 1.27 \\
\hline 16 & Besi Ø8 & 1.00 & 1.37 & 0.90 & 0.75 & 0.77 & 0.76 & 0.75 & 1.23 & 1.25 & 1.27 \\
\hline 17 & Kawat baja & 1.00 & 1.26 & 0.86 & 0.94 & 1.04 & 0.99 & 1.31 & 1.24 & 1.08 & 0.85 \\
\hline 18 & Kaca 3 mm & 1.00 & 1.41 & 0.76 & 1.37 & 1.37 & 0.48 & 0.70 & 0.86 & 0.91 & 0.88 \\
\hline 19 & Tripleks 6 mm & 1.00 & 1.47 & 0.82 & 0.85 & 0.88 & 0.89 & 0.88 & 0.78 & 0.73 & 0.81 \\
\hline 20 & Tripleks $3 \mathrm{~mm}$ & 1.00 & 1.89 & 0.83 & 0.85 & 0.88 & 0.89 & 0.86 & 0.89 & 0.87 & 0.85 \\
\hline 21 & Seng plat bjls 36 & 1.00 & 1.66 & 1.02 & 0.77 & 0.83 & 0.82 & 0.83 & 1.02 & 0.98 & 1.08 \\
\hline 22 & $\begin{array}{l}\text { Asbes } \\
\text { gelombang }\end{array}$ & 1.00 & 1.12 & 1.09 & 1.28 & 1.31 & 1.25 & 1.34 & 1.19 & 1.30 & 1.37 \\
\hline 23 & Wuwung asbes & 1.00 & 1.12 & 1.59 & 0.89 & 0.91 & 0.74 & 0.89 & 1.16 & 1.40 & 1.21 \\
\hline 24 & Eternit asbes & 1.00 & 0.55 & 0.65 & 1.28 & 1.28 & 0.60 & 0.58 & 1.28 & 1.28 & 1.28 \\
\hline 25 & Bak mandi & 1.00 & 1.9 & 1.25 & 1.54 & 1.55 & 1.23 & 1.18 & 1.45 & 1.83 & 1.38 \\
\hline 26 & Kloset jongkok & 1.00 & 0.72 & 0.56 & 0.94 & 0.95 & 0.40 & 0.36 & 0.68 & 1.24 & 1.17 \\
\hline 27 & Floor drain & 1.00 & 3.15 & 2.75 & 4.99 & 5.20 & 1.04 & 0.83 & 2.00 & 2.00 & 2.00 \\
\hline 28 & Pipa pvc 1/2" & 1.00 & 1 . & 0.85 & 1.27 & 1.32 & 1.06 & 1.16 & 1.11 & 1.28 & 1.11 \\
\hline 29 & Keran & 1.00 & 0.10 & 0.24 & 0.21 & 0.24 & 0.06 & 0.07 & 0.23 & 0.23 & 0.23 \\
\hline 30 & Pipa PVC 4' & 1.00 & 0.59 & 1.07 & 1.00 & 1.04 & 1.14 & 0.81 & 0.41 & 0.45 & 0.41 \\
\hline 31 & Pipa PVC 3" & 1.00 & 0.70 & 1.20 & 0.99 & 1.00 & 1.12 & 0.92 & 0.45 & 0.60 & 0.45 \\
\hline 32 & Titik lampu & 1. & & 0.41 & 103 & 1.07 & 0.28 & 0.24 & 0.35 & 0.40 & 0.40 \\
\hline 33 & Stop kontak & 1.00 & 0.6 & 0.56 & 1.02 & 1.02 & 0.45 & 0.43 & 0.85 & 1.36 & 1.02 \\
\hline 34 & Saklar & 1.00 & 0.71 & 0.60 & 1.24 & 1.24 & 0.51 & 0.55 & 1.91 & 2.54 & 1.53 \\
\hline 35 & Kabel & 1.00 & 1.10 & 1.06 & 0.97 & 0.98 & 1.06 & 1.00 & 1.00 & 1.36 & 1.30 \\
\hline 36 & $\begin{array}{l}\text { Panel Kontrol } \\
\text { Upah }\end{array}$ & 1.00 & 0.73 & 1.19 & 1.23 & 0.92 & 1.03 & 1.17 & 0.73 & 0.84 & 0.73 \\
\hline & - pekerja & 1.00 & 0.97 & 0.58 & 0.57 & 0.66 & 0.58 & 0.66 & 0.63 & 0.71 & 0.66 \\
\hline & - tukang batu & 1.00 & 0.99 & 0.66 & 0.60 & 0.71 & 0.66 & 0.69 & 0.65 & 0.65 & 0.65 \\
\hline & - tukang kayu & 1.00 & 0.99 & 0.66 & 0.60 & 0.71 & 0.66 & 0.69 & 0.65 & 0.65 & 0.65 \\
\hline & - tukang besi & 1.00 & 0.99 & 0.66 & 0.60 & 0.71 & 0.66 & 0.69 & 0.65 & 0.65 & 0.65 \\
\hline & - kepala tukang & 1.00 & 0.93 & 0.64 & 0.60 & 0.67 & 0.63 & 0.63 & 0.68 & 0.69 & 0.69 \\
\hline & - mandor & 1.00 & 0.76 & 0.57 & 0.53 & 0.59 & 0.56 & 0.56 & 0.59 & 0.59 & 0.57 \\
\hline
\end{tabular}

\section{Index Biaya Total Konstruksi}

Setelah melakukan estimasi dan perhitungan bobot (w) dan indeks (I) dengan cara Eurostat, dapat dilakukan perhitungan indeks biaya konstruksi (CCI). Perhitungan indeks biaya konstruksi menggunakan Rumus (7.) seperti tampak pada Tabel 3.

\section{Indeks Biaya Material (MCI) and Indeks Biaya Upah (LCI)}

Selain itu dengan rumusan dari Eurostat [9] tersebut juga dapat dilihat indeks material secara keseluruhan dan indeks biaya upah secara keseluruhan yaitu dengan rumus :

$\mathrm{MCI}=\Sigma\left(\mathrm{w}^{\mathrm{MM}} \times \mathrm{I}^{\mathrm{M}}\right)$
$\mathrm{LCI}=\Sigma\left(\mathrm{w}^{\mathrm{LL}} \times \mathrm{I}^{\mathrm{L}}\right)$

MCI dan LCI ditampilkan pada Tabel 3.

Tabel 3. Indeks Biaya Konstruksi (CCI), Indeks Biaya Material (MCI) dan Indeks Biaya Upah (LCI)

\begin{tabular}{|c|c|c|c|c|c|c|c|c|c|}
\hline No & Kota & $\mathrm{CCI}$ & MCI & $\mathrm{LCI}$ & No & Kota & $\mathrm{CCI}$ & MCI & LCI \\
\hline 1 & DKI Jakarta & 100.00 & 100.00 & 100.00 & 8 & Batang Hari & 71.84 & 75.78 & 64.33 \\
\hline 2 & Medan & 93.28 & 91.25 & 97.16 & 9 & Bungo & 73.99 & 77.57 & 67.19 \\
\hline 3 & Padang & 66.86 & 68.93 & 62.91 & 10 & Jambi & 73.94 & 78.43 & 65.38 \\
\hline 4 & Pekanbaru & 66.64 & 70.88 & 58.57 & 11 & Kerinci & 72.86 & 76.73 & 65.48 \\
\hline 5 & Kampar & 66.91 & 65.98 & 68.68 & 12 & MA Jambi & 80.95 & 90.18 & 63.38 \\
\hline 6 & Dumai & 65.64 & 67.15 & 62.76 & 13 & Merangin & 81.87 & 90.69 & 65.11 \\
\hline 7 & Inhu & 62.29 & 59.92 & 66.80 & 14 & Sarolangun & 79.90 & 87.68 & 65.11 \\
\hline
\end{tabular}


Lanjutan Tabel 3. Indeks Biaya Konstruksi (CCI), Indeks Biaya Material (MCI) dan Indeks Biaya Upah (LCI)

\begin{tabular}{|c|c|c|c|c|c|c|c|c|c|}
\hline No & Kota & $\mathrm{CCI}$ & MCI & LCI & No & Kota & $\mathrm{CCI}$ & MCI & LCI \\
\hline 15 & Tebo & 80.17 & 87.88 & 65.51 & 44 & Sumbawa & 89.15 & 101.70 & 65.27 \\
\hline 16 & Palembang & 81.97 & 84.26 & 77.62 & 45 & Dompu & 89.38 & 102.05 & 65.27 \\
\hline 17 & Bengkulu & 94.61 & 105.56 & 73.76 & 46 & Bima/Kota & 89.48 & 102.21 & 65.27 \\
\hline 18 & Bandar Lampung & 78.02 & 89.08 & 56.97 & 47 & Kupang & 77.04 & 92.46 & 47.70 \\
\hline 19 & Tanggamus & 108.50 & 132.18 & 63.44 & 48 & Sumba Tengah & 88.40 & 109.98 & 47.34 \\
\hline 20 & Lampung Selatan & 85.72 & 103.12 & 52.61 & 49 & TTS & 79.60 & 96.49 & 47.44 \\
\hline 21 & Lampung Tengah & 79.06 & 93.59 & 51.41 & 50 & Makassar & 84.67 & 91.53 & 71.63 \\
\hline 22 & Kota Metro & 79.89 & 96.23 & 48.79 & 51 & Gowa & 84.29 & 90.94 & 71.63 \\
\hline 23 & Lampung Timur & 82.06 & 99.63 & 48.62 & 52 & Takalar & 85.70 & 93.09 & 71.63 \\
\hline 24 & Lampung Utara & 68.98 & 77.83 & 52.13 & 53 & Jeneponto & 83.55 & 89.81 & 71.63 \\
\hline 25 & Tulang Bawang & 85.53 & 99.25 & 59.41 & 54 & Maros & 82.51 & 88.22 & 71.63 \\
\hline 26 & Bandung & 77.69 & 90.85 & 52.65 & 55 & Pangkep & 83.08 & 89.09 & 71.63 \\
\hline 27 & Bekasi & 85.05 & 96.67 & 62.93 & 56 & Barru & 84.17 & 90.75 & 71.63 \\
\hline 28 & Bogor & 80.59 & 96.45 & 50.40 & 57 & Pare-Pare & 84.58 & 91.38 & 71.63 \\
\hline 29 & Kerawang & 80.71 & 93.31 & 56.74 & 58 & Bone & 81.93 & 87.34 & 71.63 \\
\hline 30 & Cirebon & 62.49 & 73.72 & 41.12 & 59 & Soppeng & 83.03 & 89.01 & 71.63 \\
\hline 31 & Semarang & 83.21 & 96.31 & 58.28 & 60 & Wajo & 83.63 & 89.94 & 71.63 \\
\hline 32 & Sleman & 80.88 & 101.15 & 42.31 & 61 & Sidrap & 84.83 & 91.77 & 71.63 \\
\hline 33 & Yogyakarta & 82.28 & 103.29 & 42.31 & 62 & Bantaeng & 84.63 & 91.47 & 71.63 \\
\hline 34 & Bantul & 81.71 & 102.42 & 42.31 & 63 & Bulukumba & 85.74 & 93.15 & 71.63 \\
\hline 35 & Kulon Progo & 85.87 & 108.76 & 42.31 & 64 & Sinjai & 87.26 & 95.47 & 71.63 \\
\hline 36 & Gunung Kidul & 91.76 & 117.75 & 42.31 & 65 & Selayar & 88.62 & 97.54 & 71.63 \\
\hline 37 & Surabaya & 92.98 & 97.37 & 84.62 & 66 & Kota Gorontalo & 74.61 & 76.42 & 71.17 \\
\hline 38 & Bali & 81.91 & 94.48 & 57.99 & 67 & Kab. Gorontalo & 73.78 & 73.92 & 73.52 \\
\hline 39 & Mataram & 84.30 & 98.83 & 56.65 & 68 & Kab. Boalemo & 73.00 & 73.29 & 72.45 \\
\hline 40 & KLU & 84.45 & 99.05 & 56.65 & 69 & Kab. Pohuwato & 71.02 & 70.76 & 71.50 \\
\hline 41 & Lombok Tengah & 84.77 & 99.55 & 56.65 & 70 & Kab Bone Belango & 73.82 & 73.65 & 74.14 \\
\hline 42 & Lombok Timur & 84.69 & 99.42 & 56.65 & 71 & Kab. Gorontalo Utara & 74.57 & 75.72 & 72.40 \\
\hline 43 & KSB & 89.26 & 101.86 & 65.27 & & & & & \\
\hline
\end{tabular}

\section{Zoning}

Untuk memudahkan penggunaan indeks yang dihasilkan, penelitian ini menggunakan enam zona indeks untuk 71 kota yang diteliti. Tabel 4 dan Gambar 3 menunjukan zona indeks CCI, Tabel 5 dan Gambar 4 untuk zona indeks MCI, serta Tabel 6 dan Gambar 5 untuk zona indeks LCI.

Tabel 4. Pembagian Zona Indeks Biaya Konstruksi (CCI)

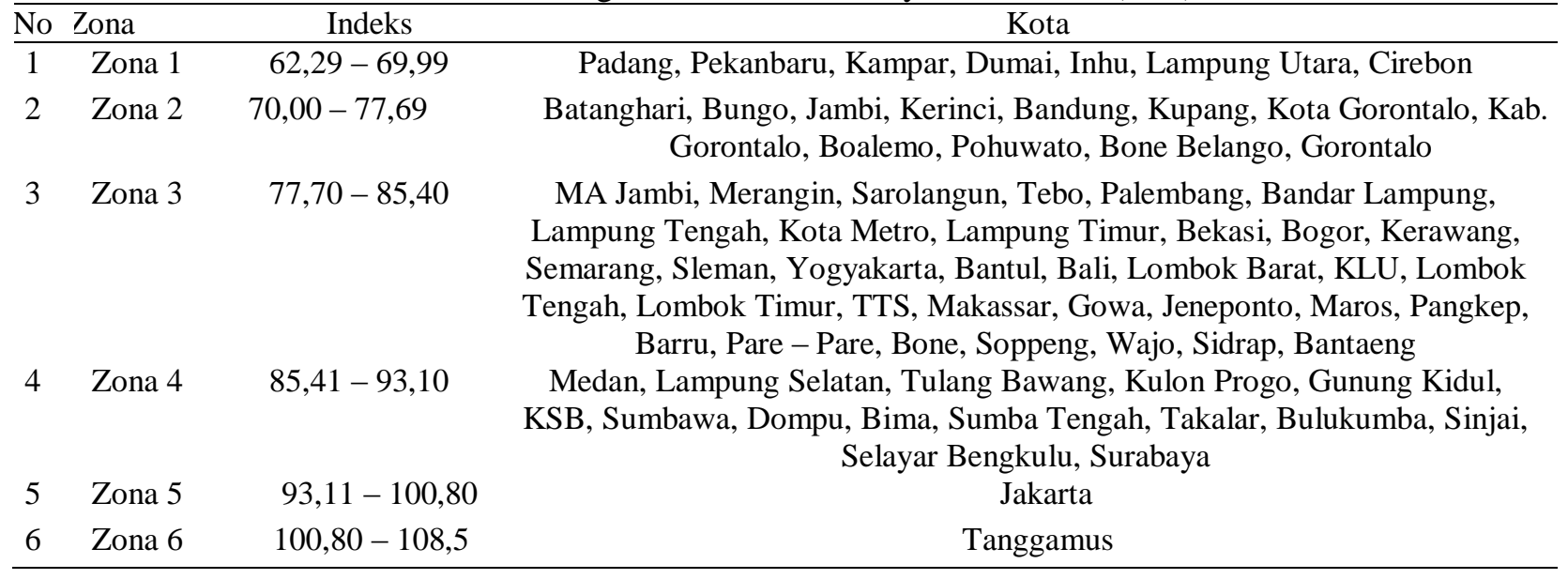




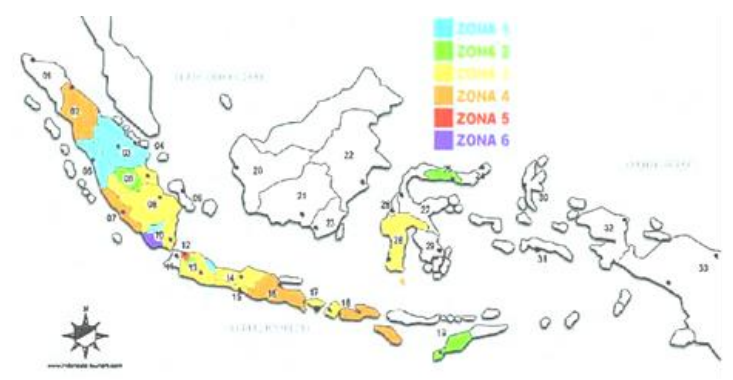

Gambar 3. Pembagian Zona Indeks Biaya Konstruksi Rumah Sejahtera Murah (CCI)

Tabel 4 dan Gambar 3 menggambarkan perbandingan Indeks Biaya Konstruksi di tiap kota dengan range Indeks Biaya Konstruksi (CCI) 62,29 - 108,50. Sebagian besar kota berada di zona 3 yaitu pada range 77,70 - 85,4. Indeks Biaya Konstruksi (CCI) tertinggi ada pada kota Tanggamus disusul oleh Jakarta. Indeks tersebut untuk melihat nilai total bangunan secara keseluruhan, sedangkan untuk melihat komposisi harga material atau upah yang lebih tinggi akan dibahas lebih lanjut di Tabel 5, Gambar 3, Tabel 6, dan Gambar 4.

Tabel 5. Pembagian Zona Indeks Biaya Material (MCI)

\begin{tabular}{|c|c|c|c|}
\hline No & Zona & Indeks & Kota \\
\hline 1 & Zona 1 & $59,92-71,96$ & Padang, Pekanbaru, Kampar, Dumai, Inhu, Pohuwato \\
\hline 2 & Zona 2 & $71,97-84,01$ & $\begin{array}{l}\text { Batang Hari, Bungo, Jambi, Kerinci, Lampung Utara, Cirebon, Kota } \\
\text { Gorontalo, Kab. Gorontalo,Boalemo, Bone Belango, Gorontalo Utara }\end{array}$ \\
\hline 3 & Zona 3 & $34,02-96,05$ & $\begin{array}{l}\text { Medan, MA Jambi, Merangin, Sarolangun, Tebo, Palembang, Bandar } \\
\text { Lampung, Lampung Tengah, Bandung, Kerawang, Bali, Kupang, Makassar, } \\
\text { Jowa, Takalar, Jeneponto, Maros, Pangkep, Barru, Pare - Pare, Bone, } \\
\text { Soppeng, Wajo, Sidrap, Bantaeng, Bulukumba, Sinjai }\end{array}$ \\
\hline 4 & Zona 4 & $36,06-108,09$ & $\begin{array}{l}\text { Jakarta, Bengkulu, Lampung Selatan, Metro, Lampung Timur, Tulang } \\
\text { Bawang, Bekasi, Bogor, Semarang, Sleman, Yogyakarta, Bantul, Surabaya, } \\
\text { Lombok Barat, KLU, Lombok Tengah, Lombok Timur, KSB, Sumbawa, } \\
\text { Dompu, Bima, TTS, Selayar }\end{array}$ \\
\hline 5 & Zona 5 & $108,10-120,14$ & Kulon Progo, Gunung Kidul, Sumba Tengah \\
\hline 6 & Zona 6 & $120,15-132,18$ & Tanggamus \\
\hline
\end{tabular}

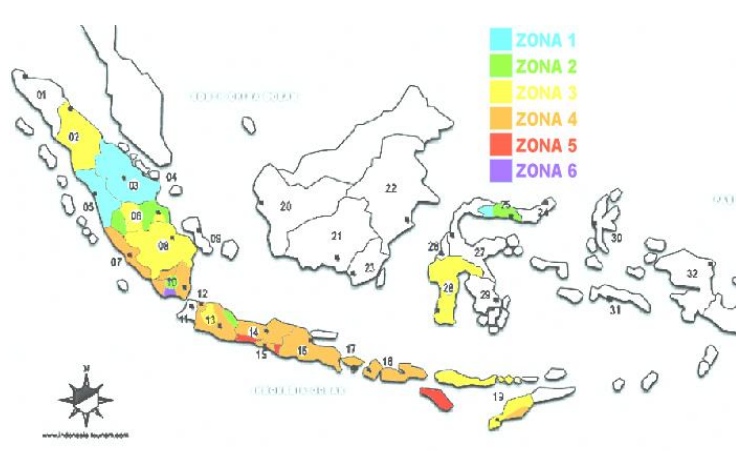

Gambar 4. Pembagian Zona Indeks Biaya Material (MCI)
Tabel 5 dan Gambar 4 menunjukan bahwa Indeks Total Material (MCI) berada di range indeks 59,92 - 132,18, dimana kebanyakan kota berada di Indeks Biaya Material (MCI) di Zona 3 dan Zona 4 yaitu range 84,01 - 108,09. Indeks Biaya Material (MCI) tertinggi berada di kota Tanggamus, disusul dengan Kulon Progo, Gunung Kidul dan Sumba Tengah. Indeks Biaya Material (MCI) Jakarta berada di Zona 4. 
Tabel 6. Pembagian Zona Indeks Biaya Upah (LCI)

\begin{tabular}{|c|c|c|c|}
\hline No & Zona & Indeks & Kota \\
\hline 1 & Zona 1 & $41,12-50,93$ & $\begin{array}{l}\text { Metro, Lampung Timur, Bogor, Cirebon, Sleman, Yogyakarta, Bantul, } \\
\text { Kulon Progo, Gunung Kidul, Kupang, Sumba Tengah, TTS }\end{array}$ \\
\hline 2 & Zona 2 & $50,94-60,75$ & $\begin{array}{l}\text { Pekanbaru, Bandar Lampung, Lampung Selatan, Lampung Tengah, } \\
\text { Lampung Utara, Tulang Bawang, Bandung, Kerawang, Semarang, Bali, } \\
\text { Lombok Barat, KLU, Lombok Timur }\end{array}$ \\
\hline 3 & Zona 3 & $60,76-70,56$ & $\begin{array}{l}\text { Padang, Kampar, Dumai, Inhu, Batang Hari, Bungo, Jambi, Kerinci, MA } \\
\text { Jambi, Merangin, Sarolangun, Tebo, Tanggamus, Bekasi, KSB, Sumbawa, } \\
\text { Dompu, Bima }\end{array}$ \\
\hline 4 & Zona 4 & $70,57-80,37$ & $\begin{array}{l}\text { Palembang, Bengkulu, Makassar, Gowa, Takalar, Jeneponto, Maros, } \\
\text { Pangkep, Barru, Pare - Pare, Bone, Soppeng, Wajo, Sidrap, Bantaeng, } \\
\text { Bulukumba, Sinjai, Selayar, Kab.Gorontalo, Kota Gorontalo, Boalemo, } \\
\text { Pohuwato, Bone Belango, Gorontalo Utara }\end{array}$ \\
\hline 5 & Zona 5 & $80,38-90,19$ & Medan, Surabaya \\
\hline 6 & Zona 6 & $90,20-100$ & Jakarta \\
\hline
\end{tabular}

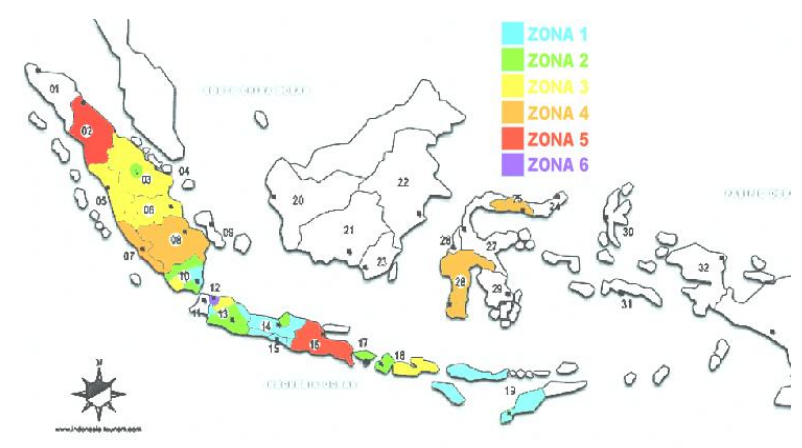

Gambar 5. Pembagian Zona Indeks Biaya Upah (LCI)

Dari Tabel 6 dan Gambar 5 tampak bahwa variasi Indeks Biaya Upah (LCI) berada di range 41,12 - 100. Kebanyakan kota berada di zona 2 - zona 4 yaitu di range index 50,93 - 80,37. Indeks Biaya Upah (LCI) tertinggi adalah Jakarta disusul dengan Medan dan Surabaya. Dengan melihat zonasi kota Jakarta dimana Indeks Biaya Upah (LCI) berada di zona 6 dan Indeks Biaya Material (MCI) berada di zona 4 maka penyebab komposisi Indeks Biaya Bangunan (CCI) Jakarta tinggi adalah upah yang tinggi. Sedangkan kota Tanggamus memiliki komposisi biaya material yang tinggi yaitu di zona 6 bila dibanding upah yang berada di zona 3. Dari zonasi kota Jakarta dan Tanggamus dapat dilihat bahwa penyebab komposisi Indeks Biaya Konstruksi (CCI) tinggi antar kota tidaklah sama tergantung pada sumber daya di masing - masing wilayah. Perlu perhatian yang khusus dalam melakukan estimasi biaya maupun cost control pada masing - masing komposisi Indeks Biaya Konstruksi (CCI) tinggi.

\section{KESIMPULAN}

Indeks Biaya Konstruksi (CCI) dibentuk dari bobot material dan upah (w) di kota dasar dan Indeks Biaya Material $\left(\mathrm{I}^{\mathrm{M}}\right)$ dan Indeks Biaya Upah $\left(\mathrm{I}^{\mathrm{L}}\right)$. Masing - masing daerah memiliki Indeks Biaya Material $\left(\mathrm{I}^{\mathrm{M}}\right)$ dan Indeks Biaya Upah $\left(\mathrm{I}^{\mathrm{L}}\right)$ yang berbeda beda. Pada penelitian menunjukan sebaran Indeks Biaya Konstruksi (CCI) di Indonesia adalah 62,29 - 108,50 dengan dasar kota Jakarta yaitu 100. Hanya Indeks Biaya Konstruksi (CCI) kota Tanggamus lebih tinggi dari indeks Jakarta. Indeks Biaya Konstruksi (CCI) yang terbentuk dapat dipecah lagi menjadi Indeks Biaya Material (MCI) dan Indeks Biaya Upah (LCI). Indeks Biaya Upah (LCI) dan Indeks Biaya Material (MCI) tiap daerah memiliki perbedaan. Misalnya Padang memiliki Indeks Biaya Material (MCI) lebih tinggi dari pada Indeks Biaya Upah (LCI). Sedangkan Pekanbaru, Indeks Biaya Upah (LCI) lebih tinggi daripada Indeks Biaya Material (MCI). Untuk kota Jakarta, penyebab Indeks Biaya Konstruksi (CCI) yang tinggi adalah biaya upah yang tinggi bahkan tertinggi di Indonesia.

Indeks Biaya Konstruksi (CCI), Indeks Biaya Material (MCI), dan Indeks Biaya Upah (LCI) yang sudah terbentuk dapat diplotkan dalam zona - zona untuk 
memudahkan melihat distribusi harga. Pembagian zona dibagi dalam 6 bagian. Dari

\section{DAFTAR PUSTAKA}

Asworth, A, 1988, Cost Studies of Buildings. Singapore : Longman Singapore Publisher (Pte) Ltd.

Badan Standar Nasional Indonesia, 2011, Handbook Standar Nasional Indonesia (SNI) tentang Tata Cara Perhitungan Harga Satuan untuk Bangunan Gedung dan Perumahan tahun 2011. Jakarta : author.

Deng et al (2010), Economic Growth and the Expansion of Urban Land in China, Urban Studies; Vol. 47, No. 4, 813 834.

Eurostat, 2006, Methodology of Short-term Business Statistics : Interpretation and Guidelines.

Gockov et al (2012), The Role, Significance, and Trend of Construction Sector in Macedonia, Research Gate.

Hwang, S (2009), Dynamic Regression Models for Prediction of Construction Cost, Journal of Construction Engineering and Management 135, 360375.

Libianto, T. T., 2016, Perbandingan Biaya Total, Material, dan Upah Konstruksi Rumah Sejahtera Murah antar Daerah di Indonesia Tahun 2015, Surabaya : Universitas Kristen Petra.

Memon et al, (2010), Factor Affecting Construction Cost in Mara Large Construction Project : Perspective of Project Management Consultant, International Journal of Sustainable Construction Engineering and Technology; Vol. 1, No. 2, 41-54.

Menteri Pemukiman dan Prasarana Wilayah Republik Indonesia, 2002, Keputusan Menteri Pemukiman dan Prasarana zona ini dapat dilihat penyebaran dan perbedaan indeks harga antar kota.

Wilayah Nomor:403/KPTS/M/2002 Pedoman Teknis Pembangunan Rumah Sederhana Sehat (Rs Sehat), Jakarta : author

Oginni et al (2014), Comparative Study of Price Variations of Basic Civil Engineering, Energy and Environment Research; Vol. 4, No. 3, 50 - 57.

Pandu Bangun Persada Nusantara (2015), Jurnal Harga Satuan Bangunan Konstruksi dan Interior Edisi XXXIV. Jakarta : author.

Pratt, J. W. (1987), Dividing the Indivisible: Using Simple Symmetry to Partition Variance Explained. Proceeding of the 2nd International Tampere Conference, 245-260.

Santoso, I. (1999), Analisa Overruns Biaya pada Beberapa Tipe Proyek Konstruksi, Civil Engineering Dimension Vol. 1., 40-48.

Statistic Directorate (n.d.), Sources and Methods Construction Price Indices, Paris : Organisation for Economic Cooperation and Development.

Skitmore et al (2006), Construction price formation: full-cost pricing or neoclassical microeconomic theory?, Journal of Construction Management and Economics, Vol. 24, No. 7, 773783.

Wibowo et al (2013), Menuju Indeks Biaya Konstruksi Rumah Sejahtera Murah (IBK-RSM), Paper presented at Seminar Nasional IX-2013 Teknik Sipil ITS Surabaya.

Yu, M.K.W., dan Ive, G. (2008), The Compilation Methods of Building Prices in Britain : a Critical Review, Journal of Construction and Economics; Vol. 26, 693-705. 